\title{
The development of teaching materials oriented to critical thinking skills for chemistry class XI high school
}

\author{
Risma Siahaan ${ }^{1, *}$, Marham Sitorus ${ }^{2}$ and Saronom Silaban ${ }^{2}$ \\ ${ }^{1}$ Chemistry Education Study Program, Postgraduate, Universitas Negeri Medan, Medan 20221, \\ Indonesia \\ ${ }^{2}$ Department of Chemistry, Universitas Negeri Medan, Medan 20221, Indonesia \\ *Corresponding author: RS, cheasyo2@gmail.com
}

DOI: $10.24114 / j p k i m . v 13 i 1.24145$

Article history:

Received: 27 February 2021

Revised: 26 March 2021

Accepted: 26 March 2021

Abstract: This study aims to determine the feasibility of teaching materials oriented critical thinking ability grade XI SMA developed. This research includes research and development with 3D development model (define, design and develop). The teaching materials developed were validated based on aspects of material feasibility, language and media by experts using validation sheets in accordance with BSNP standards and then the validated teachng materials were distributed to two teachers and grade XI students at Sultan Agung Private High School and SMAN 1 Pematangsiantar to find out the response of teachers and students using questionnaires. The results of the study found that expert validation of teaching materials developed has an average score of 4.17 in terms of content feasibility, 4.20 for the aspect of presentation feasibility, 4.33 for the linguistic aspect and 4.19 from the aspect of graphation. While students' response to critical thinking ability-oriented module teaching materials had average scores of 3.80 and 3.82 and teacher responses averaged a score of 4.27 , judging by interest indicators, material indicators and language indicators. These results show that the critical thinking ability-oriented teaching materials developed have met valid and good criteria for use.

Keywords: Teaching materials, Critical thinking skills, Chemical equilibrium, 3D models

\section{Introduction}

Chemistry is one of the subjects taught at the high school (Fauzi et al. 2021). Chemistry learning is also a means of learning and thinking training, not just memorizing concepts. Chemistry learning consists of three aspects of study, including macroscopic, microscopic and symbolic aspects. Basically, the three aspects of chemistry learning studies require a higher level of student thinking. One part of high-order thinking is critical thinking, which is a thought process to decide and draw accountable conclusions based on relevant data, including analysis, hypotheses, 
explaining, arguing and developing thoughts (Ihsan et al. 2019). Subjects, especially chemistry, are a tool to achieve goals, to be able to train students to have thinking skills. One of the things that needs to be developed in chemistry learning is critical thinking skills, in accordance with the objectives of chemistry education. Chemical materials and critical thinking skills are two things that cannot be separated, because chemistry is understood through critical thinking and vice versa, critical thinking can be trained through learning chemistry (Silaban, 2017; Silaban, 2021). Critical thinking skills are one of the most important goals in all levels of education. The ability to think critically cannot develop along with the physical development of each individual. This ability is related to the ability to identify, analyze, and solve problems creatively and logically so as to produce appropriate judgments and decisions (Fakhriyah, 2014).

The implementation of chemistry learning in many schools tends to pay less attention to the development of students' critical thinking skills. Chemistry learning is more theoretical in nature, memorizing or factual knowledge, this makes chemistry learning not in line with the goals of national education. The learning model or method used by many chemistry teachers tends to be a teacher centered by using direct learning methods. Learning patterns are dominated by teachers, especially in the transfer of knowledge to students. The ability to think critically for each individual is different, depending on the exercises that are often done to develop critical thinking.

According to Haryati et al. (2019) one of the efforts that teachers can make to achieve national goals is to develop teaching materials into various forms of teaching materials. Teaching materials that can be used by students as a source of independent learning have an important role in improving and developing students' critical thinking skills. But in reality, teaching materials such as handbooks owned by teachers and students still tend to be the same. In general, handbooks owned by teachers and students from several publishers contain mostly explanations of material or concepts, sample questions and practice questions or assignments that students must do. Examples of existing questions and exercises also do not develop and stimulate students' critical thinking skills, so that in solving the practice questions there are still many students who have difficulty. The development of appropriate teaching materials and in accordance with a student learning needs is the best effort to be able to improve student learning outcomes and foster students' critical thinking skills. Siagian et al. (2016), explained that "improving the quality of learning will lead to improve the quality of human resources and the welfare of the community. One effort that can be done is through improving learning resources".

Several previous studies related to the development of teaching materials have been carried out. Demircioğlu et al. (2005), reported that the learning outcomes of students who were taught using teaching materials that were designed according to the needs and circumstances of students showed a significant increase in learning 
outcomes. The results of research by Hera et al. (2014), concluded that the contextual-based embryology learning handout developed was deemed appropriate and able to improve students' conceptual understanding of embryology material in Animal Development lectures. The results of Lasmiyati and Harta (2014) research show that the learning modules developed are declared feasible and there is an increase in concepts between students who use modules and those who do not. Another study conducted by Manalu et al. (2016) also obtained the learning outcomes of students who were taught using innovative chemistry modules higher than the learning outcomes of students who were taught without innovative chemistry modules or by using textbooks. This is supported by Prabowo et al. (2016), showed that the learning modules developed were feasible and effective in supporting learning activities. Lubis et al. (2019), concluded that the learning module developed was feasible and effective in improving student learning outcomes. Sari et al. (2019), concluded that the developed module can be used as a learning resource that helps students learn independently.

\section{Methods}

This research was conducted at the SMA Swasta Sultan Agung Pematangsiantar and SMAN 1 Pematangsiantar, North Sumatra. The research period is planned to be carried out from July to Augus 2020. The subjects of this development research consist of: 1) instrument validators; 2 ) expert validators, namely material experts and media experts; 3) chemistry teacher; and 4) students of class XI SMA Swasta Sultan Agung Pematangsiantar and SMAN 1 Pematangsiantar. While the object of this research is module oriented to critical thinking skills in the chemical equilibrium material for class XI SMA to be developed.

This research is a type of research and development (R\&D) that is a type of research that produces a product instead of testing a theory. In this study, product development was focused on teaching materials oriented to critical thinking skills in learning chemistry on chemical equilibrium material for class XI SMA. The development model used in this development research is the $3 \mathrm{D}$ development model proposed by Thiagarajan and Semmel (Trianto, 2014), which includes the following stages: define, design, and develop.

The technique of processing and analyzing data in research and development is carried out in several stages as follows:

\subsection{Validity analysis}

The validation data of experts is analyzed taking into account the inputs, comments, and suggestions of validators. The results of the analysis are used as a guide for revising the teaching materials developed. The measurement scale on the validation sheet uses a scale of 5 (five). The average score of the validation results is 
obtained from the total score of the validation results divided by the number of aspects assessed, using a formula (Sudjana, 2016):

$$
\begin{aligned}
\overline{\mathrm{X}} & =\frac{\sum \mathrm{X}_{\mathrm{i}}}{\mathrm{n}} \\
\overline{\mathrm{X}} & =\text { Average validation score } \\
\sum \mathrm{X}_{\mathrm{i}} & =\text { The total score of the validation results } \\
\mathrm{n} & =\text { Number of aspects assessed }
\end{aligned}
$$

Furthermore, the average score obtained was interpreted in the validation category according to Arsyad (2016), as in the Table 1.

Table 1

Product validity category

\begin{tabular}{c|c}
\hline Scor Interval & Category \\
\hline $4.10<\overline{\mathrm{X}} \leq 5.00$ & Very Valid \\
\hline $3.10<\overline{\mathrm{X}} \leq 4.10$ & Valid \\
\hline $2.10<\overline{\mathrm{X}} \leq 3.10$ & Valid enough \\
\hline$\overline{\mathrm{X}}<2.10$ & Invalid \\
\hline
\end{tabular}

\subsection{Teacher and student response analysis}

Responses to teaching materials developed were analyzed based on the results of questionnaires that have been filled by teachers and students. In this study, the rating score measurement scale was used on a scale of 5 (five). The steps in data analysis are as follows:

a. collect raw data in the form of the results of teacher and student questionnaires

b. scoring the results of the questionnaire

c. calculate the average score of the questionnaire results, with the formula (Sudjana, 2016):

$$
\begin{aligned}
\bar{X} & =\frac{\sum X_{i}}{n} \\
\bar{X} & =\text { Average questionnaire score } \\
\sum X_{i} & =\text { The total score from the questionnaire results } \\
n & =\text { Number of items on the questionnaire }
\end{aligned}
$$

Table 2

Teacher and student response questionnaire category

\begin{tabular}{c|c}
\hline Score Interval & Category \\
\hline$\overline{\mathrm{X}}>4.20$ & Very Good \\
\hline $3.40<\overline{\mathrm{X}} \leq 4.20$ & Good \\
\hline $2.60<\overline{\mathrm{X}} \leq 3.40$ & Good Enough \\
\hline $1.80<\overline{\mathrm{X}} \leq 2.60$ & Less \\
\hline$\overline{\mathrm{X}} \leq 1.80$ & Not Good \\
\hline
\end{tabular}


The average score obtained is a number then interpreted in a qualitative sense according to the assessment criteria according to Widoyoko (2016), as in the Table 2.

\section{Results and Discussion}

The results of this development research are chemistry teaching materials/ modules oriented to critical thinking skills for grade XI SMA students. Module teaching materials are developed using a $3 \mathrm{D}$ development model consisting of define, design, and develop and are designed in the format or form of printed teaching materials in the form of modules with A4 size $(21 \times 29.7 \mathrm{~cm})$.

\subsection{Expert Validation Results}

Teaching materials in the form of critical thinking ability-oriented chemistry modules for high school grade XI students that have been designed are validated by expert validators to analyze the feasibility of the module (Table 3 ).

Table 3

Material expert validation results

\begin{tabular}{l|c|c}
\hline \multicolumn{1}{c|}{ Assessment Aspects } & Mean Score & Criteria \\
\hline Content Feasibility According to BSNP & 4.17 & Very Valid \\
\hline Presentation Feasibility According to BSNP & 4.20 & Very Valid \\
\hline Linguistic Feasibility According to BSNP & 4.33 & Very Valid \\
\hline Total Mean & 4.23 & Very Valid \\
\hline
\end{tabular}

Table 3, shows that the results of the assessment (validation) by material expert validators obtained an average total score of 4.23 or classified as very valid criteria. In the aspect of feasibility, the content is stated to be very valid with an average score of 4.17; on the feasibility aspect of the presentation it was stated very valid with an average score of 4.20; and the aspect of linguistic feasibility is declared very valid with an average score of 4.33 . Thus, from the assessment results by material expert validators it was concluded that the teaching materials of critical thinking abilityoriented chemistry modules for grade XI high school students were declared very valid based on aspects of content feasibility, presentation and language according to BSNP.

The results of the assessment (validation) by the media expert validator obtained an average total score of 4.19 or classified as very valid criteria. Thus, from the results of the assessment by media expert validators, it was concluded that the chemistry module teaching materials were oriented towards critical thinking skills for high school students of class XI declared very valid based on the feasibility aspect of the graphic according to BSNP.

The results of the assessment by the two expert validators (material experts and media experts) show that the teaching materials for the chemistry module are oriented towards critical thinking skills for class XI high school students developed 
have been declared very feasible (very valid) in terms of material aspects (content feasibility, presentation feasibility and linguistic feasibility according to BSNP) as well as from the media aspect (feasibility of graphics according to BSNP). Thus, from the results of the research of the two expert validators it was concluded that the teaching materials for the chemistry module were oriented towards critical thinking skills for students in class XI SMA that had been developed and were feasible to conduct development trials on target users, namely students and teachers.

\subsection{Teacher Response Questionnaire Result}

Development trials were also carried out on chemistry teachers with the aim of analyzing the teacher's response to the chemistry module teaching materials that were oriented towards critical thinking skills for the developed XI grade students of SMA. The number of teachers who were the subject of research as many as 2 chemistry teachers from Sultan Agung Pematangsiantar Private High School and SMAN 1 Pematangsiantar.

Table 4

Teacher response questionnaire results

\begin{tabular}{l|c}
\hline \multicolumn{1}{c|}{ Aspek Penilaian } & Mean Score \\
\hline Interest & 4.25 \\
\hline Theory & 4.04 \\
\hline Language & 4.83 \\
\hline Total Mean & 4.28 \\
\hline
\end{tabular}

Table 4 shows that the results of development trials conducted on 4 class XI chemistry teachers at SMA Swasta Sultan Agung Pematangsiantar and SMA Negeri 1 Pematangsiantar, obtained an average score on the interest indicator of 4.25 (very good); on the theory indicator of 4.04 (good); the language indicator is 4.83 (very good); and overall the teacher response from the questionnaire results obtained an average of 4.28 (very good). Thus, from the results of the teacher's response questionnaire, it can be concluded that the teacher's response to chemistry module teaching materials is oriented towards critical thinking skills for grade XI high school students which resulted in a very good average.

\subsection{Student Response Questionnaire Results}

The development trial is a product trial activity that is produced on the real target subject, namely to students and teachers as product users. Development trials are carried out with the aim of analyzing the responses or reactions of students and teachers as target users of the module teaching materials being developed. Development trials were carried out on class XI IPA-2 students of SMA Swasta Sultan Agung Pematangsiantar (36 students) and class XI IPA-1 students of SMAN 1 SMA Pematangsiantar (36 students). 
Table 5 shows that the results of development trials conducted on Sultan Agung Pematangsiantar high school students, obtained an average score on the interest indicator of 3.81 (good); on the theory indicator of 3.69 (good); and the language indicator for 3.97 (good); and overall obtained an average of 3.80 (good). Furthermore, the results of the development trial for SMAN 1 Pematangsiantar showed that the average score on the interest indicator was 3.80 (good); on theory indicators of 3.74 (good); and the language indicator is 4.00 (good); and overall obtained an average of 3.82 (good). Thus, based on the results of a questionnaire from Sultan Agung Pematangsiantar students and SMAN 1 Pematangsiantar students, it can be concluded that the students' responses to chemistry module teaching materials oriented to critical thinking skills for class XI SMA students are on average good.

Table 5

Student response questionnaire results

\begin{tabular}{l|c|c}
\hline \multirow{2}{*}{ Assessment Aspects } & \multicolumn{2}{|c}{ Mean Score } \\
\cline { 2 - 3 } & SMA Swasta Sultan Agung & SMA Negeri 1 \\
\hline Interest & 3.81 & 3.80 \\
\hline Theory & 3.69 & 3.74 \\
\hline Language & 3.97 & 4.00 \\
\hline Total Mean & 3.80 & 3.82 \\
\hline
\end{tabular}

The chemical equilibrium module was developed with the criteria of FRISCO critical thinking ability presented by Ernis (Fridanianti et al. 2018) namely focus, reason, inference, situation, clarity, overview contained in the material description, learning activities, training questions and student worksheets. As stated by Hasruddin (2009) that students will have a deep understanding when the learning process emphasizes critical thinking ability. This is reinforced by the results of research by Lestari et al. (2019) that there is a positive correlation between student learning outcomes and critical thinking skills. In accordance with the aspects of the learning process according to the 2013 curriculum, learning should emphasize student's engagement to express their ideas on a problem and provide opportunities for students to develop independently through their thinking process. Learning using modules according to Prastowo (2012) will improve students' ability to learn independently so that they exert their thinking skills in mastering the concept of the material being studied. This happens as the module has directions on how to master the important points in the materials, activities that must be done by students in constructing the material through reasoning critical thinking questions, and the description of the material compiled is more complex and easier to understand by students. 


\section{Conclusion}

Critical thinking ability-oriented teaching materials for students on grade XI high school on chemical equilibrium materials developed with 3D models are designed in the form of printed-teaching-materials modules. Critical thinking ability-oriented teaching module materials for students on grade XI high school are declared very feasible (very valid) based on the validator assessment of material experts and media experts reviewed from aspects of content feasibility, feasibility of presentation, language feasibility and aspects of eligibility according to BSNP. The overall teachers' responses was also classified as very good criteria (average score of 4.28) as well as students' response to teaching materials of critical thinking ability-oriented modules on the subject matter of chemistry equilibrium grade XI of high school classified as good criteria (average score of 3.80 and 3.82) reviewed from indicators of interest, material indicators and language indicators. These results showed that the critical thinking ability-oriented chemical equilibrium module developed has met valid criteria and is proper in chemical learning.

\section{Acknowledgment}

The author would like to thank the principals, chemistry teachers and students of the SMA Swasta Sultan Agung Pematangsiantar and SMA Negeri 1 Pematangsiantar and all participants who have contributed and supported in this development research.

\section{References}

Arsyad, N. (2016). Model pengembangan pembelajaran menumbuhkembangkan kemampuan metakognitif. Makassar: Pustaka Refleksi.

Demircioglu, G., Ayas, A., \& Demircioglu, H. (2005). Conceptual change achieved through a new teaching program on acids and bases. Chem. Educ. Res. Pract, 6(1), 36-51. DOI: 10.1039/b4rp90003k

Fakhriyah, F. (2014). Penerapan problem based learning dalam upaya mengembangkan kemampuan berpikir kritis mahasiswa. Jurnal Pendidikan IPA Indonesia, 3(1), 95-101.

Fauzi, F., Erna, M., \& Linda, R. (2021). The effectiveness of collaborative learning throughtechniques on group investigation and think pair share students' critical thinking ability on chemical equilibrium material. Journal of Educational Sciences, 5(1), 198-208. DOI: 10.31258/jes.5.1.p.198-208

Fridanianti, A., Purwati, H., \& Murtianto, Y. H. (2018). Analisis kemampuan berpikir kritis dalam menyelesaikan soal aljabar kelas VII SMP N 2 Pangkah ditinjau dari gaya kognitif reflektif dan kognitif impulsif. AKSIOMA: Jurnal Matematika Dan Pendidikan Matematika, 9(1), 11. DOI: 10.26877/aks.vgi1.2221

Haryati, S., Erviyenni, E., Putri, M.A., \& Albeta, S.W. (2019). Development of student activities worksheet based on a comic with $4 \mathrm{C}$ in chemical equilibrium for class $\mathrm{xi}$ high school. Jurnal Pendidikan Kimia, 11(2), 37-48. DOI: 10.24114/jpkim.v11i2.14461 
Hasruddin, H. (2009). Memaksimalkan kemampuan berpikir kritis melalui pendekatan kontekstual. Jurnal Tabularasa, 6(1), 48-60.

Hera, R., Khairil., \& Hasanuddin. (2014). Pengembangan handout pembelajaran embriologi berbasis kontekstual pada perkuliahan perkembangan hewan untuk meningkatkan pemahaman konsep mahasiswa di Universitas Muhammadiyah Banda Aceh. Jurnal EduBio Tropika. 2(2): 223-229.

Ihsan, M. S., Ramdani, A., \& Hadisaputra, S. (2019). Efektivitas model blended learning dalam pembelajaran kimia untuk meningkatkan kemampuan berpikir kritis peserta didik. Jurnal Pijar Mipa, 14(2). DOI: 10.29303/jpm.v14i2.1238

Lasmiyati, L., \& Harta, I. (2014). Pengembangan modul pembelajaran untuk meningkatkan pemahaman konsep dan minat SMP. Pythagoras: Jurnal Pendidikan Matematika, 9(2), 161174 .

Lestari, R.P., Damanik, M., \& Kembaren, A. (2019). The development paired cards using problem based learning on student competency. Jurnal Pendidikan Kimia, 11(3), 100-106. DOI: 10.24114/jpkim.v11i3.15738

Lubis, S. F., Ellizar, E., \& Sukardi, S. (2019). Development of traditional bun arrangement module for 11th grade students in state vocational high school. Budapest International Research and Critics in Linguistics and Education (BirLE) Journal, 2(4), 329-337. DOI: 10.33258/birle.v2i4.520

Manalu, E., Silaban, S., Silaban, R., \& Hutabarat, W. (2016). The development of chemical practice guidebook colloid system-based integrated contextual character values. Jurnal Pendidikan Kimia, 8(2), 87-89.

Prabowo, C. A., Ibrohim, I., \& Saptasari, M. (2016). Pengembangan modul pembelajaran inkuiri berbasis laboratorium virtual. Jurnal Pendidikan: Teori, Penelitian, dan Pengembangan, 1(6), 1090-1097.

Prastowo, A. (2012). Panduan kreatif membuat bahan ajar inovatif. Yogyakarta: DIVA Press

Sari, F. A., Suseno, N., \& Riswanto, R. (2019). Pengembangan modul fisika online berbasis web pada materi usaha dan energi. JIPFRI (Jurnal Inovasi Pendidikan Fisika Dan Riset Ilmiah), 3(2), 129-135. DOI: 10.30599/jipfri.v3i2.476

Siagian, P., Simanjuntak, E., \& Samosir, K. (2016). Prototype pembelajaran matematika SMA sesuai kurikulum 2013 untuk meningkatkan kemampuan pemecahan masalah di Provinsi Sumatera Utara. Jurnal Penelitian Bidang Pendidikan, 22(2), 91-108.

Silaban, S. (2017). Dasar-dasar pendidikan matematika dan ilmu pengetahuan alam. Medan: Harapan Cerdas Publisher.

Silaban, S. (2021). Pengembangan program pengajaran. Medan: Yayasan Kita Menulis.

Sudjana, N. (2016). Penilaian hasil proses belajar mengajar. Bandung: Remaja Rosdakarya Offset.

Trianto. (2014). Desain pengembangan pembelajaran tematik. Jakarta: Bumi Aksara.

Widoyoko, E.P. (2016). Evaluasi program pembelajaran panduan praktis bagi pendidik dan calon pendidik. Yogyakarta: Pustaka Pelajar. 